\title{
Dramaturgia pojęć
}

ABSTRACT. Krajewska Anna, Dramaturgia pojęć [Dramaturgy of concepts]. „Przestrzenie Teorii” 36. Poznań 2021, Adam Mickiewicz University Press, pp. 7-13. ISSN 1644-6763. DOI 10.14746/ pt.2021.36.0.

The article is an introduction to the dramaturgies in contemporary humanities and focuses on the problem of the dramaturgy of concepts. Using Olga Tokarczuk's example of the "tender narrator" and Wisława Szymborska's poem Night, it shows different ways of creating attitudes towards the disintegration of the vision of the world based on the topos of the Book.

KEYWORDS: dramaturgy of concepts, dramaturgical literary studies, "tender narrator", Olga Tokarczuk, Night, Wisława Szymborska, mysterium tremendum, literalness, metaphor, drama

Tematyczny numer „Przestrzeni Teorii” Dramaturgie wspótczesnej humanistyki prezentuje różne spojrzenia na przestrzenie humanistyki, które łączy perspektywa związana z dramatem. Jednak to, co stanowi główne przesłanie wydania, nie mieści się jedynie w udowadnianiu, że humanistyka współczesna jest dramatyczna. Nie potrzeba wielkiej wnikliwości wzroku, by odnotować dramaturgiczny wymiar zjawisk nie tylko dotyczaccych działań artystycznych, zwłaszcza literatury i teatru, lecz także obejmujących funkcjonowanie całej sfery kultury. Powiedzieć, że świat wokół nas nie odsyła już do wielkich narracji, w których wszystkowiedzący narrator odgrywa rolę autorytetu, to o wiele za mało. Narracji rozsypanej, rozrzuconej, pofragmentowanej, pociętej złożyć się już nie da. Mówiąc słowami Tadeusza Różewicza: „to się złożyć nie może”. Rozsypana narracja ułożyła się jednak w niezwykłą dramaturgię! Stała się ruchoma, opowiada w działaniu, słowa prowokuja, wymykając się szpaltom gazet, przekraczając kartki drukowanych książek, zmieniając nośniki na elektroniczne. Słowa są wszechobecne, trafiaja na billboardy, są unoszone na kartonach, zapełniają mury, spoglądają z ekranów. Słowa przechodzą w obraz, stając się przedmiotami wizualnymi. Słowa wybrzmiewają w konkretnym głosie, są czytane, wypowiadane, recytowane, śpiewane, eksponując materię akustyczną. Słowa zaczepiaja, prowokuja, zniewalaja, kłamia, krzycza, łamią się, przechodząc w milczenie. Wielka Księga na naszych oczach rozpada się na kawałki niczym zbita tafla lustra, a szklane odłamki kaleczą jej strony i nasze ciała. Świat się rozpadł, rozpada każdego dnia.

Wraz z upływem czasu również słowa się starzeją banalizuja, stają się wytrychem otwierającym każde drzwi. Prześledźmy jeden z wątków 
dotyczący takich procesów. Spróbujmy uchwycić dramaturgię ruchu pojęć, zmiany ich sensu, gdy wychodzą poza znaczenie literackie lub łamią bariery dyscyplin. Pojęcia czytane w zmiennych kontekstach ich użyć sa przechwytywane. Pojęcia wobec siebie tworza konstelacje. Pojęcia, przekraczając granice dziedzin, przerzucając mosty między nauką i sztuka, są obdarzane innymi zakresami znaczeń. Pojęcia, udzielając sobie nawzajem cech - splątują się. Każde z takich działań ma swoją teorię. Traktowane jako hasła, wymykaja się usztywnieniu przez definicje. Nie miejsce tu na powtarzanie obrazowych określeń, jak „pojęcia operacyjne”, „wędrówka pojęć”, „walczące słowa”, „błądzące słowa”, „pojęcia płynne”, „zawieszenia percepcji”, „splatanie”, „przechwytywanie”, „stapianie”, „splątanie” itp. . Drogę oddziaływania pojęć pokażmy zatem krótko na paru przykładowych zbliżeniach ilustrujacych najbardziej widoczne w humanistyce procesy zwiazane z dramatyzacją dyskursów, wybierzmy grę dosłowności i przenośni, upotocznienia i interpretacyjnej wieloznaczności.

W przypadku Olgi Tokarczuk dotyczy to choćby upotocznienia pojęcia „czułego narratora” (przechodzenie z filozoficznej metafory do banalnej potoczności użycia zwrotu), które stało się faktem, pozwalającym na wchłonięcie przez pole należące do tzw. skrzydlatych słów. W przypadku Wisławy Szymborskiej można pokazać drogę od przewrotnej wykładni opowieści biblijnej z wiersza Noc (wieloznaczność słów dotyczących przechodzenia z dosłowności do przenośni) do przeistoczenia się w całkowite swoje zaprzeczenie w naiwnej, szkolnej interpretacji (czyli zaniku ironii w dosłowności uproszczonego odczytania). Gdy Olga Tokarczuk mówiła o „czułym narratorze" w swym wykładzie noblowskim, wydawać się mogło (i z cała pewnością tak było), że uruchomiła - nie tyle chrześcijańska, co kulturowo odmienna, związana z filozofią Dalekiego Wschodu - perspektywę patrzenia na świat poprzez pojęcie czułości i, dodajmy, współczucia. Uaktywniając podejście do świata wiążące je z kategorią czułości rozumianej jako współodczuwanie - jednak nie w znaczeniu zachodnioeuropejskiej empatii, ale raczej w sensie buddyjskiego pojęcia współczucia jako wyrazu jedności bytu, mimo cierpienia przenikającego całe istnienie - przyjęła postawę trudnej afirmacji, przygarniającej i ocalającej. Opowieść o świecie autorki Prawieku... to propozycja nieco odmienna od wyrazu buntu Wisławy Szymborskiej, która w słynnym wierszu Noc, nawiązującym do biblijnej opowieści o Abrahamie, od którego Bóg zażądał złożenia w ofierze ukochanego, jedynego syna Izaaka, dostrzegła możliwą heroiczną obronę człowieczej godności w prawie do odmowy ocalenia. Przenosząc biblijną perspektywę oglądu i umieszczając

${ }^{1}$ Listę określeń i ich twórców wymieniam i omawiam szerzej w artykule Teoria splatana, „Przestrzenie Teorii” 2020, nr 34, s. 8/9. 
ją w podmiocie będącym dzieckiem, w rzeczywistości kazała nam patrzeć oczami Izaaka, ale poprzez taki zabieg pozwoliła też na stworzenie pozornie naiwnej opowieści o świecie zła i okrucieństwa widzianych oczami dziecka - dziecka, które ukrywa się i boi, ale też równocześnie, pokonując lęk, stawia opór. W tym pozornie tylko dziecięcym oporze robienia „na złość" dorosłym, a naprawdę w rozpaczliwym, dojrzałym geście buntu, mieści się walka o prawo do wolności wyboru swego losu.

\author{
Czeka Pan Bóg \\ i z balkonu chmur spoziera, \\ czy się ładnie, czy się równo \\ stos zapali \\ i zobaczy, \\ jak na przekór się umiera, \\ bo ja umrę, \\ nie pozwolę się ocalić!
}

Po latach określenie Tokarczuk „czuły narrator” nie tylko stanie się tytułem ponoblowskiej książki, będącej zbiorem esejów (Czuły narrator), lecz także często nadużywaną kalką. Śledzimy dramaturgię pojęcia, które z filozofii przeszło do mowy potocznej, zatracając głębię skojarzeń i pojemność refleksji (np. „czuły ogrodnik” czy „czuły barbarzyńca” to jednak nie to samo co „czuły narrator”), po drodze zbanalizowało się, tracąc pole znaczeniowe wyznaczone przez noblistkę. Podobnie dzieje się z interpretacją wiersza Szymborskiej. Głęboko tragiczny wiersz Noc kończy się fragmentem:

\author{
Od tej nocy \\ ponad miarę złego snu, \\ od tej nocy \\ ponad miarę samotności, \\ zaczął Pan Bóg \\ pomalutku \\ dzień po dniu \\ przeprowadzkę \\ $\mathrm{z}$ dosłowności \\ do przenośni.
}

Zacytowany fragment wiersza, stanowiący jego pointę, jest ironiczny, podkreśla tragizm, uwydatnia ciche nawiązanie do Sørena Kierkegaarda mysterium tremendum. Nie możemy zrozumieć naszej kondycji, tkwimy w pułapce bytu, uzależnieni od siły z innego, nieludzkiego (w podwójnym znaczeniu słowa: zarówno niebędącego człowiekiem, jak i zimnego, cechującego się brakiem empatii) wymiaru, porządku, którego praw nie jesteśmy w stanie 
pojać, ale też nie mamy sposobów, by przedrzeć się przez ludzki ograniczony zasięg słów i pojęć. Wykładnia Szymborskiej - jak sądzę - współgra z wywodem Jacques'a Derridy z tekstu Darować śmierć. A może nawet idzie jeszcze dalej. U Derridy Abraham w swym milczeniu jest całkowicie samotny, uwięziony w granicach własnego ,ja”, nie dzieli się z nikim odpowiedzialnościa, nie przerzuca jej w słowach na innych. Mówienie bowiem to wkraczanie na teren języka, które przynosi ulgę, bo przekłada się na to, co powszechne. A etyczne ustala się właśnie na podstawie tego, co powszechne ${ }^{2}$. Szymborska poszerza perspektywę patrzenia, wprowadzając wypowiedź dziecka. Bliska być może byłaby poetce wizja Józefa Wittlina z wiersza Lament barana ofiarnego, w którym autor także zmienia opcję patrzenia i zamiast rozterek wewnętrznych Abrahama, pokazuje chwilę po ocaleniu Izaaka, ale wtedy, gdy milknie opowieść, udziela głosu zwierzęciu:

\section{Dlaczego ja? Dlatego żem zwierzę \\ I nie mam duszy? A za to mam rogi \\ Mocno w cierniowym krzaku zaplątane \\ Tak abym nie mógł uciekać przed nożem \\ Obłąkanego z przerażenia starca?}

W wierszu Wittlina znajdziemy wers-pytanie: „Musiałaż być spełniona ta ofiara? / Nie dość Mu, że poigrał sobie z sercem starca". Gdyby przyjać plan utworu Szymborskiej, to okaże się on korespondujący nie tylko z czterokrotnym przedstawieniem sceny biblijnej u Kierkegaarda, lecz także właśnie $\mathrm{z}$ wierszem Wittlina, poprzez dramaturgiczną wielogłosowość (w wierszu Wittlina mową jest obdarzone zwierzę ofiarne - $\mathrm{i}$ to $\mathrm{w}$ jego imieniu, $\mathrm{z}$ jego pozycji patrzymy na starannie układany stos). Podczas gdy w wierszu Szymborskiej patrzymy oczami dziecka przeznaczonego na ofiarę, przeczuwającego śmierć, u Kierkegaarda mówią cztery wersje, w których zmieniają się akcenty, przesuwaja punkty widzenia, przy pozorach opowiedzenia i przedstawienia pozornie tożsamej wersji wydarzeń głosem jednego narratora. W istocie jednak w każdej z wersji zmieniamy warianty konsekwencji zdarzeń. Dramaturgia biblijnej sceny (nie komplikując już tekstu o serie malarstwa przedstawiającego ofiarowanie Izaaka) rozgrywa się w przecięciu różnych punktów widzenia, w potencjalności przewidywanych i rzeczywistych skutków decyzji rozgrywających się jednak we wnętrzu obdarzonej odpowiedzialnościa jednostki, w psychice Abrahama. Słowa i pojęcia nie wystarczaja, przemawiają silniej doświadczenie i wyobraźnia oparta na doznaniach zmysłowych. O ile u Kierkegaarda rzecz rozgrywa się przede

${ }^{2}$ J. Derrida, Darować śmierć, przeł. K. Liszka, M. Pawlikowska, „Odra” 2004, nr 12, s. $38-48$. 
wszystkim w myślach i jedynie drobne, pozornie niezauważalne gesty, jak np. drżenie ręki zaciśniętej na nożu, odsyłają do reakcji ciała, o tyle u Wittlina doznania somatyczne stają się pierwszoplanowe (walące ze strachu serce zaplątanego w gałęzie krzewu zwierzęcia odczuwającego ból), u Szymborskiej do głosu dochodzi estetyka afektu (porażający lęk, nieufność i zwątpienie), a także pojawiający się motyw snu zasłaniającego inną rzeczywistość, wzbudzajacego poczucie niepewności ontologicznej.

Jakichkolwiek byśmy trzymali się wykładni - to przecież my sami stwarzamy hipotezy, próby odpowiedzi, dlaczego było możliwe tak nieludzkie „poigranie z uczuciami starca”. Zasłaniamy dosłowność (tak rozpaczliwie trudną do przyjęcia!) przenośnią (,balsamem przypowieści”, jej metaforyczną wykładnia). To my z ludzkiej perspektywy staramy się zawiesić przerażająca dosłowność, wytwarzając uspokajające nas sensy. Szymborska w istocie stawia pytanie o celowość braku „czułego narratora”. A co, jeżeli istnieje tylko dosłowność i nie ma żadnego balsamu przenośni? Podobnie jest u Herberta w wierszu Jonasz, w którym „balsam przypowieści nie ima się jego ciała”3.

W internecie można znaleźć też liczne „bryki”, pseudoanalizy utworu wprowadzajace proste wyjaśnienia przesłania wiersza Szymborskiej - oto opowieść biblijna, która nie powinna być czytana dosłownie, ale metaforycznie (przeszła z dosłowności do przenośni). Trudno tę naiwność przyjąć bez dystansu...

Te dwa przypadki: spopularyzowanie zwrotu Tokarczuk z wykładu noblowskiego oraz interpretacja frazy kończącej wiersz Szymborskiej, pokazuja, jak działaja pojęcia. Łączy je w obu przypadkach skłonność do proliferacji; u Tokarczuk wejście „czułego narratora” do sfery kultury popularnej pomnożyło sensy zwrotu, nadało mu jednak nieco inne znaczenia, stało się powtórzeniem na miarę sztuki kopii w plastyce. U Szymborskiej proliferacja dotycząca możliwych wykładni opowieści biblijnej okazuje się $\mathrm{w}$ istocie proliferacja ontologiczna, generuje sposoby kreowania rzeczywistości, światów możliwych.

Obserwacja zjawiska przejmowania pojęć literackich i uruchomianie ich w sferze życia codziennego każą nam zastanawiać się nad rola przejmowanych słów kształtujących scenę naszych zachowań - nie tylko językowych. Czułość, z nieco wstydliwie ukrywanej, stała się kategoria pierwszoplanowa. Czułość wysunęła się na przód sceny. Przedstawiona interpretacja wiersza Szymborskiej może natomiast prowadzić do refleksji na temat mocy słów w ukrywaniu naszych podejrzeń, braku odwagi w stawianiu niewygodnych pytań, niepokojów, lęków, przerażeń. Bo przecież jest to wiersz o pojęciach, dramatyczny wiersz o dramaturgii pojęć.

${ }^{3}$ Z. Herbert, Jonasz, [w:] Wiersze zebrane, Warszawa 1971, s. 247. 
Wyrafinowanym czytelnikom „Przestrzeni Teorii”, literaturoznawcom czy teatrologom te zjawiska są znane; wydaje się, że ich opis nie może już wnieść nic nowego. Przytoczyłam je jednak, jako rodzaj case studies, właśnie z literatury, i to nie z dramatu, lecz z prozy (wykład noblowski, potem tytuł zbioru esejów Tokarczuk) i liryki (wiersze Szymborskiej, Wittlina, Herberta), by zaakcentować, że „to, co mówione” w literaturze, jest też tym, co poprzez literature ,jest czynione”. Pokazać słowa w działaniu, słowa, które nie tylko starają się nazwać, coś przekazać, zbudować, lecz także mogą chcieć coś ukryć, wyretuszować, zasłonić. Słowa i pojęcia znaczą nie tylko wtedy, gdy powstaja, lecz także i wtedy, gdy się rozpadaja, bledna, zacieraja, znikaja. Oto ich dramaturgia. W końcu, żeby podkreślić rolę, jaką odgrywają przemieszczenia pojęć w przekształcaniu dyskursu humanistycznego w dyskurs dramaturgiczny.

$$
* * *
$$

Temat numeru, podjęty z inspiracji poznańsko-krakowskiej grupy badawczej, zespołu współpracującego w ramach projektu badań nad dramaturgia, został sformułowany nieco przewrotnie. Zależało nam bowiem w Redakcji nie tylko na konkretnych tekstach i problemach, lecz także na obserwacji nieprzewidywalnego procesu, który pokaże dramaturgia numeru. Chcieliśmy zobaczyć scenę nieoczekiwanych spotkań pojęć dramaturgicznych. Byliśmy ciekawi, jak Autorzy będą używać pojęć, które z nich zdominuja, które zmienią znaczenie, które stworzą aporię, którym będziemy się bacznie przyglądać. Dlatego (proszę wybaczyć odsłanianie kulis tuż przed spektaklem...) nie wysyłaliśmy specjalnych zaproszeń do osób zajmujących się dramatem, nie selekcjonowaliśmy podejmowanych tematów ani nie ingerowaliśmy zbyt mocno w sposoby ich ujęć. Dramaturgia numeru okazała się ciekawa poprzez rozległość problemów: twarz i maska w filozofii i styk dramaturgii z poezja, dramat i transgresja, kultywowanie sztuki umierania i nowy model komunikacji literackiej, neomodernizm filmowy i dramaturgia współtworzenia znaczeń, komunikacja i dramatyzacja, muzyka i fotografia, performatywne aktorstwo i performatywne kategorie estetyczne, teatr agonistyczny i dramaturgia kolorów historii, deziluzja w filmie i performans postcyfrowy, retrospektywy i konfrontacje z kanonem, żeby wymienić choć niektóre z nich. Ten numer traktujemy jako zaproszenie do kontynuacji refleksji nad dramaturgicznym charakterem współczesnego literaturoznawstwa. 


\section{BIBLIOGRAFIA}

Derrida J., Darować śmierć, przeł. K. Liszka, M. Pawlikowska, „Odra” 2004, nr 12, s. $38-48$.

Herbert Z., Jonasz, [w:] Wiersze zebrane, Warszawa 1971, s. 247.

Kierkegaard S., Bojaźń i drżenie. Choroba na śmierć, z oryginału duńskiego przeł. i wstępem opatrzył J. Iwaszkiewicz, Warszawa 1972.

Krajewska A., Teoria splatana, „Przestrzenie Teorii” 2020, nr 34, s. 8/9.

Szymborska W., Noc, [wiersz z tomu Wołanie do Yeti, w:] Wiersze wybrane, Kraków 2000, s. 23-25.

Tokarczuk O., Czuły narrator, przemowa noblowska Olgi Tokarczuk, Svenska Akademien, The Nobel Foundation 2019.

Wittlin J., Lament barana ofiarnego, [za:] J. Abramowska, Pisarze w zwierzyńcu, Poznań 2010, s. 13.

Anna Krajewska - prof. zw. dr hab., redaktor naczelna czasopisma teoretycznoliterackiego „Przestrzenie Teorii” oraz serii Biblioteka Przestrzeni Teorii. Założycielka i kierowniczka Zakładu Estetyki Literackiej Instytutu Filologii Polskiej Uniwersytetu im. Adama Mickiewicza w Poznaniu w latach 2003-2021. Zajmuje się literaturoznawstwem, zwłaszcza teorią dramatu, estetyką literacką i performatywna. Autorka licznych prac poświęconych teorii i estetyce współczesnego dramatu, w tym książek: Komedia polska dwudziestolecia międzywojennego. Tradycjonaliści i nowatorzy (Wrocław 1989 wyd. I, Poznań 2004 - wyd. II), Dramat i teatr absurdu w Polsce (Poznań 1996), Dramat wspótczesny. Teoria i interpretacja (Poznań 2005), Dramatyczna teoria literatury (Poznań 2009). W przygotowaniu: Splatany świat, t. 1 Humanistyka performatywna, t. 2 Estetyka antybinarna. ORCID: 0000-0001-5622-0852. Adres e-mail: <akraj@amu.edu.pl>.

Anna Krajewska - full professor, Ph.D (dr. hab.), editor-in-chief of the literary theory journal "Przestrzenie Teorii" and the Przestrzenie Teorii Library series. Initiator and head of the Unit for Literary Aesthetics at Adam Mickiewicz University in Poznań from 2003-2021. She deals with literary studies, especially the theory of drama, literary and performative aesthetics. Author of numerous works on the theory and aesthetics of contemporary drama, including: Komedia polska dwudziestolecia międzywojennego. Tradycjonaliści i nowatorzy [Polish Comedy of the Inter-war Period. Traditionalists and Innovators] (Wrocław 1989 - 1st ed., Poznań 2004 - 2nd ed.); Dramat i teatr absurdu $w$ Polsce [Drama and the Theatre of the Absurd in Poland] (Poznan 1996); Dramat wspótczesny. Teoria $i$ interpretacja [Contemporary Drama. Theory and Interpretation] (Poznań 2005); Dramatyczna teoria literatury [Dramatic Literary Theory] (Poznań 2009). She is currently writing: Splatany świat, t. 1 Humanistyka performatywna, t. 2 Estetyka antybinarna [Entangled World, vol. 1 The Performative Humanities, vol. 2 Anti-binary Aesthetics]. ORCID: 0000-0001-5622-0852. E-mail address: <akraj@amu.edu.pl>. 